\title{
Fisheries discard as an alternative for agricultural feed in the state of Campeche, Mexico
}

\author{
Bautista-Ortega J. ${ }^{1}$; Rosales-Martínez V. ${ }^{1-2}$; Santillán-Fernández A. ${ }^{1-2}$; Huicab-Pech Z. G. ${ }^{{ }^{*}}$ y Galicia-Galicia F. ${ }^{4}$ \\ ${ }^{1}$ Colegio de Postgraduados-Campus Campeche, Km. 17.5 Carretera federal Haltunchén-Edzná \\ CP. 24450, Sihochac, Champotón, Campeche. México. ${ }^{2}$ Cátedras CONACYT. ${ }^{3}$ Investigador \\ independiente. Cd. Concordia, CP. 24085, Campeche, Campeche. México. ${ }^{4}$ Investigador \\ Independiente. Agua Santa, Comapa, Veracruz, CP. 94210.
}

*Corresponding Author: zulema_hp@hotmail.com

\begin{abstract}
Objective: To determine the incidence of non-target fishing species, in riparian fishing, as a dietary alternative for the agricultural sector in the state of Campeche, Mexico.

Design/methodology/approach: The ports surveyed in the state of Campeche: Champotón, Seybaplaya and Campeche. A total of 89 questionnaires were applied at random and at the free will to participate to coastal fishermen. The obtained data were analyzed with the R vr 3.4.4 statistical software.

Results: The results showed that the coastal fishing catch is $760.1 \mathrm{~kg}$ on average/week, and fishing discards of $30.42 \mathrm{~kg} /$ week. Of the bycatch, $68.8 \%$ is discarded and the rest sold at a low price (US \$ 0.2). Among the waste products, 34 species stand out, but seven represent the $58.7 \%$ of maximum incidence, mainly Bosh Ariopsis felis, Chac-chi Haemulon plumierii, Cojinuda Caranx crysos, Ixpil Upeneus sp., Macabi Elops saurus, Postà Bairdiella chrysoura and Sardina Herengula jaguana. Delimitations/implications: There is a wide variety of species of which their potential as a protein source is unknown, which can be used as input in feed
\end{abstract}

Findings/conclusions: Registered fishing discards are made up of more than 30 non-target species and according to their incidence can be considered as inputs in feed manufacturing for the agricultural sector.

Keywords: artisanal fishery, source of animal protein, feed ingredient.

\section{INTRODUCTION}

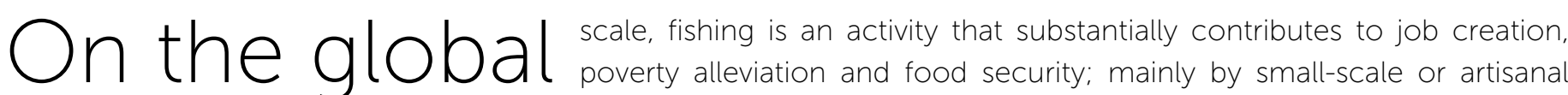
fisheries in coastal areas of developing countries (Bené et al. 2007). The per capita fish consumption was 3.2\% (20.5 kg), surpassing beef consumption, sheep and pork (2.8\%), except for poultry which represents 4.9\% (FAO, 2018). Fishing

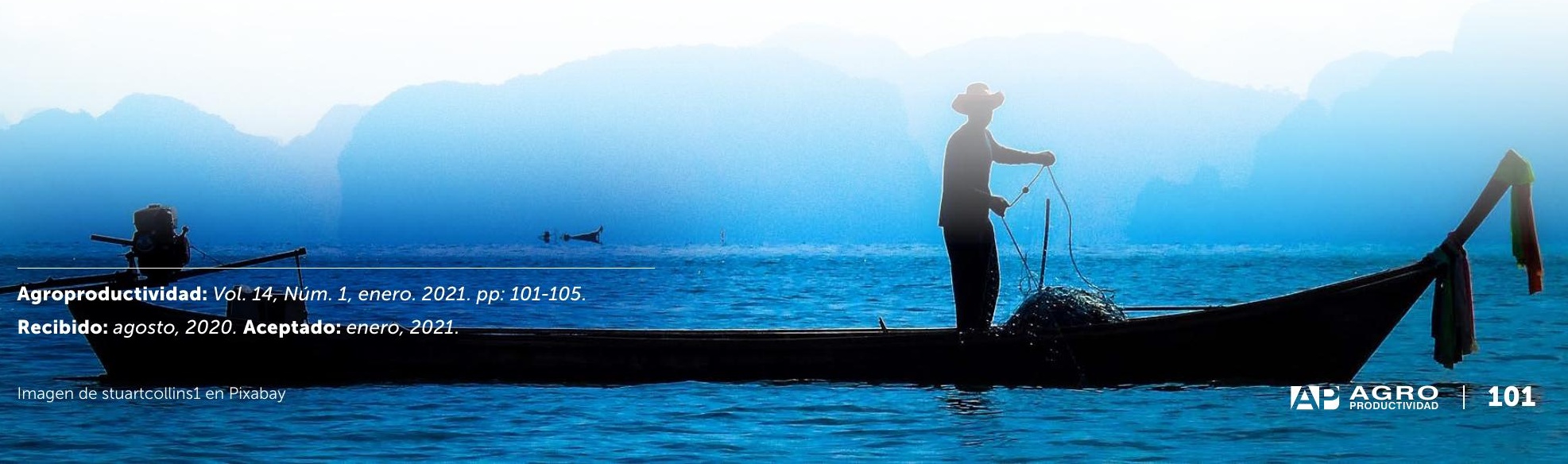


in Mexico takes place both in the Pacific and Atlantic oceans where the main sought species are shrimps, oysters, coastal and oceanic pelagic fish (grouper, mullet, sardine), which are of high commercial value and higher consumption. The Campeche coastline has a length of $523.3 \mathrm{~km}$, where three municipalities and twelve coastal communities are located, with a fishing discharge of $407,889 \mathrm{t}$ (SEPESCA, 2019). Nevertheless, fishing activity is at its maximum exploitation limit (FAO, 2018). As a result of this, aquaculture activities have been generated as a source of animal protein, based on the cultivation of marine and freshwater species, from the management of reproducers, maintenance of fry, juveniles and adults, their feeding, management and harvesting (FAO, 2019).

In recent years, aquaculture faces problems related to water consumption, excessive cost of electricity and feed. The latter depends on the protein added to the feed, its efficiency depends on its high concentrations of fish meal (protein) and fish oil (lipids) obtained from forage fish (Hua et al., 2019). The main input in the manufacture of balanced feed is the anchovy species (Engraulis ringens), which produces between 25 and 30\% of the fishmeal and fish oil in the world for the pharmaceutical, livestock, aquaculture and poultry industries (Samamé-Panta, 2019).

This species provides a concentrated source of highquality protein, omega-3 fatty acids, DHA and EPA that intervene in animals' growth (Valenzuela et al., 2012). The livestock sector directly depends on feed as the main input for production, to meet this requirement, incorporation of protein of animal origin is required. Various ingredients have been evaluated as a feed alternative based on seaweed (Beneitez and Rincones et al., 2008), insect meal, seeds, fruits, meat by-products (blood meal and bone meal) and microbial proteins (Gasco et al., 2016) designed for the agricultural sector. However, few studies report the usage of artisanal fishing by-products as an alternative ingredient for feed preparation and manufacture. For this reason, the objective of this research was to determine the incidence of nontargeted fishing species, in coastal fishing, with no commercial value but that can be a protein source in manufacturing commercial feed for the agricultural sector in the state of Campeche, Mexico.

\section{MATERIALS AND METHODS}

Between September and December 2019, coastal fishermen from three ports with economic importance were surveyed: Champotón, Seybaplaya and Campeche, located at the north and central coast of the state. The ports were selected taking into account their geographic location, the discharge volume and the characteristics of their fishing fleet (riverside). A total of $n=89$ questionnaires were applied to fishermen. The questionnaires were applied at random and at the free will of the participants. The questionnaire was structured in three sections, the first collected general information about the interviewees, while the second and third sections focused on obtaining information on the captured organisms (species) and social and economic aspects that include the weekly total weight, the amount from it for self-consumption, the species caught and those discarded for its low commercial value. The data were analyzed and descriptive statistics performed with the $\mathrm{R}$ vr 3.4.4 statistical software.

\section{RESULTS AND DISCUSSION}

The results showed that fishing is the main source of employment for the populations near the coast, which concurs with Carranza (1967), who emphasizes this activity in Campeche has a long tradition due to its social and economic impact. In this region, the fishing production chain is made up of permit holders, fishermen, private companies, and commercial fishing that send their products to local and regional markets. The foregoing also coincides with Gutiérrez-Zavala and Mancilla (2012) who show that the direct actors of the activity are fishermen, permit holders, wholesalers and retail fishing distributors.

The fishing activity in the state of Campeche is carried out by people 48.5 years mean age $(n=77 \pm 14.64)$. Results also indicated that the persons who engage in fishing are mostly mature, which also coincides with that reported by Vidal (2013) and Gravez et al. (2009) who mentioned that the workforce in fishing cooperatives in Mexico is integrated by people aged between 40 and 49 years, and in other countries, between 41 and 46.7 . Likewise, $49.3 \%$ of the fishermen reported at least 30 years of experience in the activity; $49.2 \%$ of them have primary school level and $2.8 \%$ have university studies. These also concur with Vidal (2013), who reported that fishermen have basic academic degrees, as a result of the fact that fishing is carried out for most of their lives. 
Fishermen are dedicated to catching snail, crab, scale, shrimp, octopus and crab. According to Guerrero and Martinez (2020) the activity is carried out with fishing permits, this being the scale the most common, which groups species horse mackerel, snook, grouper, blondes, chac-chi, snapper, octopus and sharks. Authors such as Guerrero and Martínez (2020) highlight that fishermen distinguish two fishing groups, the first relate to commercially important fishing (octopus and conch), the second, to marine scale fishing of low and medium economic value.

The mean scale catch per week was $628.8 \mathrm{~kg}$ ( $n=67 \pm 0.93), 115.3 \mathrm{~kg}$ of Octopus maya ( $n=21 \pm 149), 10$ $\mathrm{kg}$ of Callinectes sapidus crab $(n=1)$ and $6 \mathrm{~kg}$ of Menippe mercenaria moro crab $(n=1)$. Scale species represent the largest catch, and are generally made up of demersal species, elasmobranchs, crustaceans, and mollusks. Of the total catch, a mean of $4.3 \mathrm{~kg}(n=73 \pm 4.37)$ is destined for the fisherman's family, who consume it 2.5 times per week $(13.1 \%)$, data comparable with that reported by Cifuentes-Lemus et al. (1990), who mention that the catch volume is divided into two types, subsistence fishery, which satisfies the needs of the fisher's family, and the commercial one, which generates profits and goods, and includes community members (other permit holders).

Thirty-four point one percent of fishermen commercialize their catch in local markets or nearby towns. Twenty-six percent sell it to packers, and $12.3 \%$ sell it to freezers. Seventeen point seven percent of that sold to packers or freezers are destined for national sale, and only $1.3 \%$ is sold to the national market directly. Also, the results indicated that most of the catch is destined to the local community or surrounding areas, and a minimum amount $(1.3 \%)$ is destined for national commercialization; these commercialization differences are compared with those reported by Fischer and Espejo (2004), who propose four channels or levels of distribution for consumer producers; where hearty fishermen meet levels 1 and 2 of the links in the distribution chain. According to Arias de León (2014), the small-scale or artisanal fishery requires labour and the participation of the owners to intensify capital through modern techniques; it also indicates that the exploited resource by the fishermen is integrated into society for self-consumption, distributors, or processing, which commonly occurs on the same day in a weekly manner, as presented here, where it is emphasized that $76 \%$ of the participants sell their product the same day,
$21.3 \%$ sell it weekly, and $2.6 \%$ sell it every two weeks. The non-targeted fishing catch is $30.42 \mathrm{~kg}$ average / week $(n=56 \pm 47.16)$, which represents $4.8 \%$ of the total catch.

Of the non-targeted catch, $68.8 \%$ is discarded, the rest is used with a low commercial value, and in some cases, more than $50 \%$ is thrown back into the sea (Pitcher and Chuenpagdee, 1994).

Fishermen in the region use this waste as bait for crab or octopus, as well as for the production of Macabi (Elops saurus) ground meat for hamburgers; however, there is no use of the non-target fishery as a source for fishmeal. In this regard, Bowzer et al. (2014) propose the production of flour-based on invasive fish species such as the Asian carp (Hypoph-thalmichthys sp.) and largemouth bass (Micropterus salmoides). Abarra et al. (2017) determined that knifefish (Chitala ornata) meal, a non-target species, contributes to growth with a good feed conversion factor and weight gain in Nilotic tilapias (Oreochromis niloticus).

The fishery for non-targeted species is not bought by the final consumers, in some cases, the fishermen give it away (6.5\%). Some sell this discard at a low price (\$ 0.2 to $\$ 0.5$ US) and represents $70 \%$ of these sales, the rest access better prices that range between $\$ 1.00$ to $\$ 3.00$ US after filleted, as is the case for macabi Elops saurus meat. However, skeleton and skin waste is not accounted for. According to Stevens et al. (2018) between 50 and $70 \%$ is made up of viscera, heads, skin, bones and blood, which could be used as an alternative protein source. According to the obtained data, there are at least seven recurrent species (58.7\%) in the three fishing ports of the state, which are: Bosh (Ariopsis feliz), Chac-chi (Haemulon plumierii), Cojinuda (Caranx crysos), Macabi (Elops saurus), Postà (Bairdiella chrysoura), Sardina (Herengula jaguana) and Dorosoma anale (Table 1).

At Campeche and Champotón ports, more than 22 non-targeted species were reported, compared to the Seybaplaya port that registered less than 15 . This difference may be due to the way fishes are captured and non-selective fishing gear used during the process, which originates the incidental species dragging. This agrees with that reported by Alverson et al. (1994) who estimated that worldwide there is a fishing discard of up to 27 million tons per year, where the excessive use of non-targeted fishing gear stands out. 
Table 1. Incidence of bycatch species from three fishing ports at the state of Campeche, Mexico.

\begin{tabular}{c|c|c|c|c|c|c|}
\multirow{2}{*}{ Common name } & \multicolumn{2}{|c|}{ Total } & \multicolumn{2}{|c|}{ Seybaplaya } & Champotón & Campeche \\
\cline { 3 - 7 } & Scientific name & Incidence & Incidence (\%) & Incidence (\%) & Incidence (\%) & Incidence (\%)
\end{tabular}

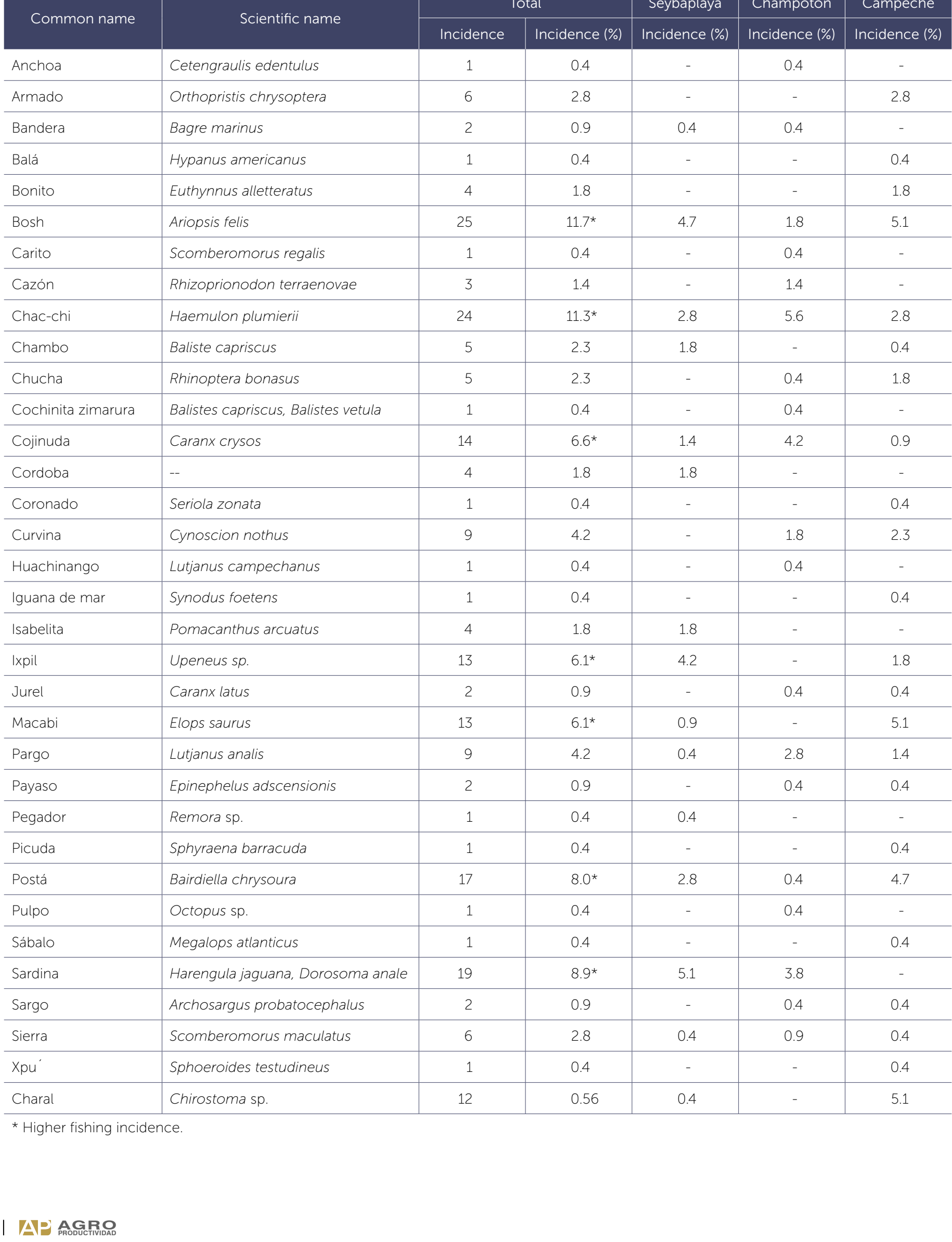

* Higher fishing incidence. 


\section{CONCLUSIONS}

The non-targeted fishing discards in the state of Campeche are made up of more than 30 species that can be valued as protein inputs for the manufacture of feed for livestock and aquaculture. Fishermen in ports indicate that these resources could represent another source of employment and wasted added value.

\section{ACKNOWLEDGEMENTS}

To the "Jóvenes Construyendo el Futuro" program and resident students at the Colegio de Postgraduados Campus Campeche livestock and forestry area for their support in the application of questionnaires in the fishing ports.

\section{REFERENCES}

Abarra, ST, Velásquez, SF, Guzman, KDD, Felipe, JLF, Tayamen, MM y Ragaza, JA (2017). Replacement of fishmeal with processed meal from knife fish Chitala ornata in diets of juvenile Nile tilapia Oreochromis niloticus. Aquaculture reports, 5, 76-83.

Alverson, DL, Freeberg, MH, Murawski, SA y Pope, JG (1994). A global assessment of fisheries bycatch and discards (Vol. 339). FAO Fisheries Technical Paper. $233 \mathrm{p}$.

Arias de León, C. (2014). La pesquería mexicana del ostión Crassostrea virginica (Gmelin, 1791) Del Golfo de México: limitantes de su desarrollo

Béné, C., Macfadyen, G., \& Allison, E. H. (2007). Increasing the contribution of small-scale fisheries to poverty alleviation and food security (No. 481). Food \& Agriculture Org.

Beneitez, M. O., \& Rincones, R. E. (2008). El cultivo de algas marinas: Alternativa industrial en Acuacultura sustentable a mediano y largo plazo. CienciaUAT, 3(2), 68-73

Bowzer, J., Bergman, A., Trushenski, J. (2014). Growth performance of largemouth bass fed fish meal derived from Asian carp. North American Journal of Aquaculture. 76 (3), 185-189.

Carranza, B, J. (1967). Marine fisheries of the Yucatan peninsula, Mexico. Proceedings of the Gulf and Caribbean Fisheries Institute, 9 , $145-150$

Cifuentes Lemus, J. L., Frías Mondragón, M., \& Torres García, P. (1990). El Océano y sus recursos: X. Pesquerías. La ciencia desde México. 87, Fondo de Cultura Económica. 229 p.

FAO Organización de las Naciones Unidas para la alimentación y la agricultura. (2019). URL: http://www.fao.org/in-action/ globefish/fishery-information/resource-detail/es/c/1242001/ [Mayo 3, 2020]
FAO Organización de las Naciones Unidas para la alimentación y la agricultura. (2018). El estado mundial de la pesca y la acuicultura 2018. Versión resumida. Cumplir con los objetivos del Desarrollo Sostenible. Pp. 30.

Fischer, L., \& Espejo J.A. (2004) Mercadotecnia. Zera Edicion. McGrawHill Interamericana Editores, México, D.F.

Gasco, L., Henry, M., Piccolo, G., Marono, S., Gai, F., Renna, M., \& Chatzifotis, S. (2016). Tenebrio molitor meal in diets for European sea bass (Dicentrarchus labrax L.) juveniles: growth performance, whole body composition and in vivo apparent digestibility. Animal Feed Science and Technology, 220, 34-45.

Gravez, V., Segura C. G. (2009). Análisis de la situación socioeconómica del sector pesquero artesanal de la isla Isabela, Galápagos. Cooperativa de pesca artesanal Horizontes de Isabel y Fundación Futuro Latinoamericano. Proyecto COPAHISAFFLA-FIA. Núm. EC-402. Ecuador: 1-17.

Guerrero, J. M. C., \& Martínez, J. D. N. (2020). Configuración Territorial de la pesca comercial ribereña en la Reserva de la Biosfera Los Petenes, Estado de Campeche (México). Estudios Geográficos, 81(288), 040

Gutiérrez Zavala, R. M., \& Mancilla, C. (2012). La pesca ribereña de Guerrero (No. F/333.956097273 G8)

Hua, K., Cobcroft, J. M., Cole, A., Condon, K., Jerry, D. R., Mangott, A., ... \& Strugnell, J. M. (2019). The future of aquatic protein: implications for protein sources in aquaculture diets. One Earth, 1(3), 316-329

Pitcher, T. J., \& Chuenpagdee, R. (1994). Bycatches in fisheries and their impact on the ecosystem.

Samamé Panta, K. L. (2019). Formulación de un proceso físico-químico para la recuperación de aceite en la empresa PRODUMARPaita.

SEPESCA. 2019. URL: http://www.sepesca.campeche.gob.mx/ boletines/definen-volumen-de-captura-criterios-de-talla-ypeso-de-pulpo-ante-apertura-de-la-temporada-de-captura/, (Julio 10, 2020)

Stevens, J. R., Newton, R. W., Tlusty, M., \& Little, D. C. (2018). The rise of aquaculture by-products: Increasing food production, value, and sustainability through strategic utilisation. Marine Policy, 90, 115-124

Valenzuela, A., Sanhueza, J., \& de la Barra, F. (2012). El aceite de pescado: ayer un desecho industrial, hoy un producto de alto valor nutricional. Revista chilena de nutrición, 39(2), 201-209.

Vidal E. (2013). Caracterización socioeconómica de la pesquería de ostión en el Golfo de México. En: Manejo de los recursos pesqueros de la cuenca del Golfo de México y del mar Caribe. D. Aldana A., M. Enríquez D., V. Elías (Eds.). La Ciencia en Veracruz. México, D.F. 114-151 pp. 